DOI: $10.7242 / 1998-2097 / 2018.4 .13$

УДК 93 / 94

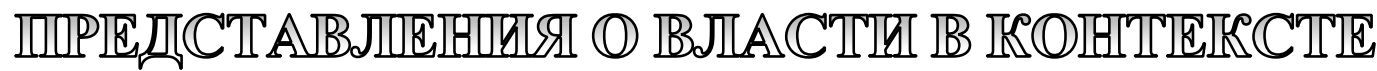

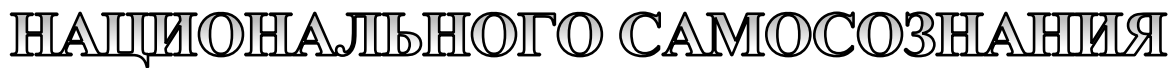

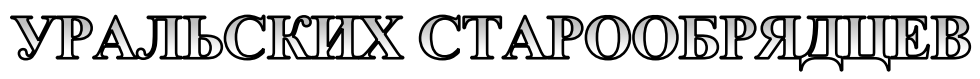

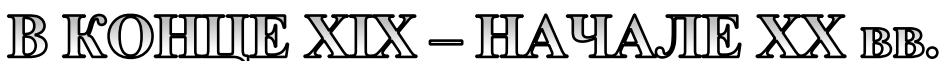

А.В. Теленков, Пермский федеральный исследовательский центр УрО РАН

В статье ставится вопрос о национальном самосознании русских старообрядцев в период серьезных исторических изменений во всех сферах жизни страны - рубеж XIX - начало XX в. (используются материалы Среднего Урала). Этот период характеризуется бурным промышленным ростом, индустриализацией, что именуется в науке термином «модернизация». Коснулись изменения и духовной жизни народа, в том числе вопросов самоидентификации. Феномен национального самосознания русских осложнен наличием значительного числа старообрядцев. Характер их этнического самосознания отличен от основной массы русского народа, в первую очередь в вопросах отношения к власти (центральной и местной). В то же время старообрядцы выступают хранителями русских традиций, культуры, книжности, что объединяет их с остальным русским народом.

Ключевые слова: начиональное самосознание, старообрядчество, православие, официальная церковь, русский народ, религиозная культура.

В современной научной и общественной мысли актуальны вопросы соотношения и взаимодействия этнической и национальной идентификаций. Говоря об этом типе идентичности, его структуре и формах проявления, следует принимать во внимание ее религиозный компонент. В особенной мере это касается этносов, находящихся в фазе традиционного общества, либо находящихся в процессе модернизации, что в полной мере применимо в отношении русских старообрядцев второй половины XIX - начала XX вв., для которых религиозная идентичность определила базовые черты этнической.

Для сообщества, имеющего значительные проблемы в осуществлении процессов внутриэтнической интеграции, неотъемлемым компонентом представлений о социо- культурном пространстве стали идеи по поводу государственной власти, являющиеся основным интегрирующим или дезинтегрирующим актором в процессах строительства нации. Историческая память об обстоятельствах церковного раскола, сопровождавшегося властным сопровождением церковной реформы, заставляла старообрядческий клир и мирян ставить отношения к власти и с властью в центр стратегии социального самоопределения и поведения. Конец XIX и начало XX веков стали периодом, в границах которого необходимость такого самоопределения усугубилась началом очередной модернизации страны. В работе для анализа специфических черт идентификационной стратегии старообрядцев использованы материалы, территориально относящиеся к региону Средне- 
го Урала как месту традиционного проживания так называемых раскольников, с дополнительной верификацией за счет источников из других регионов.

Эта тема не является, безусловно, новой для исследовательского сообщества. Первые упорядоченные и официальные сведения, а также жизнеописания о старообрядцах стали поступать от священников официального православия во второй половине XIX в. [34]. Такие исследователи, как А.П. Щапов, видели в старообрядчестве не только религиозную группу, но и комплексное социальное явление, причины которого коренятся в экономической и политической сферах, формируя народно-демократическую силу, оппозиционную власти [40]. М.М. Громыко и А.В. Буганов, изучившие огромное количество фольклорных источников XIX в., указывают на «массовость религиозного сознания» в среде русского простонародья [8, с. 7], используя для иллюстрации и старообрядческое наследие. О.П. Ершова ряд работ посвятила проблематике взаимоотношений старообрядчества с властью, рассматривая старообрядчество в трех плоскостях: как феномен традиционализма в духовной сфере (книжность, идеологические и мировоззренческие проблемы); с точки зрения положения старообрядцев в обществе и государстве, их отношения с правительственными структурами (правовая, законодательная база, борьба за права); проблемы экономической и хозяйственной жизни, история старообрядческого предпринимательства [10].

Большой вклад в изучение старообрядцев внесли Е.М. Сморгунова [29], И.В. Поздеева [25], .Н. Чагин [36], С.А. Дисмухаметова [9], С.Е. Никитина [20] и другие ученые, проводившие с начала 1970-х гг. комплексные полевые исследования в области фольклора, книжности, материальной культуры и традиций. Благодаря им накопился большой объем эмпирического материала обо всех сторонах жизни старообрядцев. В нашем случае особенно интересны духовные стихи, записанные на Среднем Урале.
С возвращением в постсоветское время интереса к вероучительной и социальной стороне религии наблюдается и активная научная деятельность по старообрядческой проблематике, особенно в регионах с традиционным проживанием этой конфессии. Так, в 2010 г. в Перми вышел сборник материалов Всероссийской научно-практической конференции «Русское старообрядчество в истории и культуре: прошлое и настоящее».

Тем не менее в настоящее время большинство аспектов религиозной и социальной жизни старообрядчества остаются незатронутыми, особенно в части определения их как специфической социокультурной группы.

Проблемная часть идейной составляющей старообрядческой идентичности имеет две составляющие: были ли старообрядцы русскими для себя и окружающих сообществ; как отражались их специфические представления о власти на осуществлении национальной самоидентификации. Ответ на оба вопроса позволит установить место старообрядцев в социальном пространстве рассматриваемого региона и объяснить доминирующие стратегии их социального же поведения.

К концу XIX в. Российская империя оставалась официально православным государством [22, с. 11] с сохранением концепта государственной религии. Эта религия рассматривалась как часть легитимации сложившейся системы управления, концентрируя отношение верующих к власти посредством церковного языка через призму образа государя как «помазанника Божия». Эта ситуация в полной мере была характерна и для Пермской губернии, свыше 95\% населения которой в начале 1860-х гг. исповедовало православие [27], с формальным сохранением этого соотношения до 1914г. [27, с. 168]. Эти цифры, внешне достаточно убедительные, требуют одной поправки - в сообщество верующих статистиками включались и 150 тысяч старообрядцев [2, с. 59].

Пермская губерния по праву считалась одним из оплотов этого направления, если можно так назвать гетерогенное со- 
общество противников реформы Никона. Территория края вмещала в себя представителей так называемых поповцев и беспоповцев, наиболее крупными из которых являлось Белокриницкое согласие, бегуны, беглопоповцы, поморцы и часовенные старообрядцы. В 1880 г. одни только беспоповцы насчитывали 52985 человек, что составляло $2,5 \%$ от общей численности жителей губернии. Однако цифры эти следует считать существенно заниженными [39, с. 81-82], поскольку «раскольники», принадлежавшие к ряду толков, всеми способами избегали официального учета.

В то же время в дореволюционной России бытовало в сознании и насаждалось властями представление о том, что русский может быть только православным $[1$, c. 86]. Эта идеологическая формулировка лишь слегка трансформировалась в связи с одним из явлений модернизационных процессов, охвативших империю в конце XIX - начале XX вв., - парламентаризмом. Для соблюдения установленной доли депутатов русской национальности от окраин возникла необходимость дать определение, кто такие русские. Ответ был дан: русские - это православные, старообрядцы и лютеране [6].

И если религиозные воззрения разделяли прихожан официальной церкви и старообрядческие общины, то принадлежность к русскому народу формально должна была объединять. Власть же в этом вопросе до закона о веротерпимости 1905 г. стимулировала переход старообрядцев в официальную церковь, заставляя конструировать собственные представления о существующей системе управления страной, отличные как от сложившейся идеологии, так и от мифологизированных представлений сторонников московского патриархата.

Официальная доктрина транслировалась через церковных иерархов, описывающих власть в терминах священного. «Без православия, - утверждали они, - не только русское общество, но и государство немыслимы». Каналом влияния на паству со стороны архипастырей были проповеди, регулярные поздравления на страницах периодической печати и выезды в местные общины. Формируя лояльное отношение православных к государственной власти, архимандриты и приходские священники всегда подчеркивали взаимозависимость религии и власти. Игумену Белогорского Свято-Николаевского монастыря Серафиму принадлежат слова: «Государь Русский, Государь Православный только и может быть Самодержавным» [3, с. 23]. Протоиерей И.Д. Лебедев, будучи кроме всего прочего еще и хорошим поэтом, сочинил народный гимн, в котором православие, Русская земля и Государь, «правды блюститель», выступают в качестве основных столпов русского народа [15].

Идеи просветительской и заступнической миссии русского царя как православного правителя высказывались и представителями интеллигенции. Так, на заседании Православного Палестинского общества вице-председателем общества Т.И. Филипповым была произнесена речь, в которой, кроме прочего, достаточно отчетливо прозвучала мысль: «Призвание России служить оплотом Церкви и быть ее оградою и упованием...». «Единый под солнцем православный государь, - продолжает оратор, - правитель Руси, приял от Бога свою власть прежде всего и более всего для охранения Его Церкви» [26]. Данная мысль имеет продолжение: через «усердие к храмам Божьим и своей любовью к Церкви православной» государь «блюдет святыню народной души» [12].

Индикатором успешности формирования таких представлений в среде мирян можно считать тот факт, что после свержения Николая II пермские крестьяне высказывали следующие соображения: «У нас нет больше Царя, нет больше отца, которого мы любили, Синод любить невозможно, а потому мы, крестьяне, хотим Патриарха» [13, с. 11]. Нельзя не увидеть, что в этих словах обоюдно отражена как роль официальной церкви в созидании конфессионального самосознания, так и его патриархальная основа.

Старообрядцы также считали себя русскими, свидетельства чему дает вышедшее в 1863 г. «Обозрение Пермского раскола», включившее в себя старообрядческие нар- 
ративы, посвященные войне с Наполеоном. Последний стойко ассоциируется Антихристом, что указывает на солидарность «раскольников» с приверженцами московской патриархии: «по еллински антихрист называется Авадон, по Еврейски Напалиен, по гречески Бонапарт, по славенски же антихрист» [23, с. 5]. В рукописи «О разделе» поморцев Пермской губернии на «максимовцев» и «деминцев» в 1866 г. говорится, что вера их «истинно православная» [24, с. 248]. Примечательны слова, сказанные неким Антинием при открытии училища в Черно-Источинском заводе, населенном старообрядцами: «Просветительная деятельность, развиваемая старообрядчеством, вполне соответствует основным, характерным запросам русского человека и неразрывно связана со всем предыдущим развитием русского народа». И далее: «Если суждено быть великой, свободной Руси - она будет, но вырастет она под лучами просвещения, принесенного из далекого прошлого старообрядчеством. Будем верить, что наше светлое будущее в развитии просвещения, в котором обретут свою свободу и русский ум и русское сердце. Будем верить с протопопом Аввакумом» [14, с. 20-22]. Все это позволяет говорить об отсутствии этнического противоречия в старообрядческой среде.

Тем не менее в представлениях о роли власти в существовании сообщества верующих старообрядцы придерживались специфической позиции. Она складывалась из нескольких компонентов. Первый был напрямую связан с представлениями о русской истории.

Часовенные старообрядцы весьма характерно представляли всемирную и русскую историю. «Когда еще были Адам и Ева, то Христос приказал им создать веру на Руси, отсюда и пошла старая вера...» [38, с. 141]. Здесь используется два способа легитимации - исконность в связи с основанием веры самим Христом и древность и тесная связь с первой человеческой парой. Текст содержит и мифологический компонент, связанный с переносом сакрального центра внутрь этнического сообщества - указание на то, что на Руси самая древняя вера.

«Идиллия» жизни в рамках «истиной» веры всей Русью, как представляли себе старообрядцы, была разрушена явлением Антихриста в лице патриарха Никона или Петра I (в источниках нет единого мнения по этому поводу). С этими именами сознание приверженцев старой веры связывало гонения и расправы. Отрицательное отношение к государственной власти во всех ее проявлениях вызывали и гражданские ограничения повседневной жизни. Только в 1822 г. администрации на местах запретили разрушать старообрядческие храмы, не разрешив строить новые. Лишь в 1830 г. старообрядцев перестали преследовать за высказывание религиозных мнений, а поповцам разрешили иметь своих священнослужителей. При Николае I стали более жесткими законодательство (в том числе уголовное) и правоприменительная практика по отношению к «раскольникам», вплоть до лишения гражданских прав и ссылки [17, с. 151-163]. Несмотря на движение внутренней политики в сторону послаблений при двух последующих императорах, отношение власти на местах зачастую характеризовалось предвзятостью и произволом.

Инициатива эта исходила от государства, поэтому вторым компонентом отношения к власти в старообрядческой среде становится критика власти. Это находило разные формы выражения. Бегуны отрицали многие атрибуты государственной власти: паспорта, ревизии душ, оброки, присягу, рекрутские наборы и т.д. [21, с. 189], поэтому предпочитали уход от мира на формальном уровне. Мир житейский рассматривался ими как «море мутное», «муть морская» $[4$, с. 126$]$, что на уровне мифовосприятия может ассоциироваться с внекосмическим, хаотическим началом.

Протест мог принять и менее выраженную форму, выливаясь в отказ участвовать в мероприятиях формального характера. Так, по случаю кончины императора Александра III один из крестьян был вызван вместе с соседями для приведения к присяге новому царю в церкви. Однако сам он «издревле состоял рас- 
кольником в староверческой религии, т.е. австрийского рукоположения священников», каковых в волости, по его словам, половина. Волостной старшина «приказал гнать всех в православную церковь». Верующий заявил, что идти не может, хотя предки его были «подписаны к Единоверию», не подчинился требованиям властей и помолился в молитвенном доме. За этот «проступок» он был вызван к земскому начальнику, который кричал и ругался «свыше всякия меры человека, превратил меня в расстройщика и совратителя, угрожал ссылкой» [7].

Этот уход от официальной церкви и власти породил особый тип личности старообрядца, описанный В.И. Немировичем-Данченко. Он передает диалог старика-старообрядца и дровосека, ставшего миллионером. Первый, говоря о лесе, в то же время раскрывает основные принципы жизни старообрядчества: «что лес, что храм - все едино... Чаща лесная злодеев праведниками делала... Святые отцы по лесу спасались, подвижники и стратиги наши от никонианских гонителей... уходили... Селами да поселками мы жили тут, и не было у нас ни татей, ни убивцев! Без закона жили, а по правде! Властей у нас не было, острогов да темниц мы не знали, не ведали, какое-такое злодейство на свете водится» [18, с. 37]. Лес становится антонимом неправедного официального, испорченного властью мира, местом спасения, залогом праведной жизни, храмом. В этом отношении происходит переход от отношения к природному как противопоставленного социуму, принципиально хаотическому, к наделению леса сотериологическими характеристиками, статусом священного. Неслучайно еще дореволюционные краеведы упоминали популярность на Урале выражения: «Жизнь за старую веру», поддерживаемого «имущими Бога» $[18$, с. 38$]$.

Однако неверным было бы представлять всех старообрядцев такими искателями духовной жизни. С конца XIX в. легально нажитое предпринимательством и торговлей богатство для части старообрядцев становится нормой. В заметках о те- атральной жизни на Урале в журнале «Репертуар и пантеон» говорилось о зрителях купеческого сословия: «Жаль, что все они почти старообрядцы или раскольники, впрочем, это не мешает им быть достойными гражданами и людьми нечуждыми общественных удовольствий» [11, с. 156].

Помимо «непротивления» злу в старообрядческой среде возникли мысли и о более решительных действиях против властей. Известно их участие в чеканке фальшивых («воровских») денег. В ряде случае эти действия помимо экономических мотивов имели и идеологический характер. Идеология странничества также предполагала открытое вооруженное противостояние властям. Один из духовных вдохновителей согласия $\mathrm{B}$. Москвин в своем труде «Разглагольствие тюменского странника» обещал последователям скорую решающую битву с «воинами Антихриста» [33, с. 161].

Сопротивление власти иногда приобретало казусный оттенок. В г. Красноуфимске в 1879 г. власти узнали о существовании нового толка, когда во время молебна по случаю покушения на жизнь государя десять человек из старообрядческой среды кричали: «Кому вы молитесь? Это антихристы». Все они, признавшиеся на допросе, что цель их была изобличение Антихриста, оказались неплательщиками податей [21, с. 238]. Чуть позже в том же Красноуфимском уезде появилась целая «секта» под названием «неплательщики», сформировавшие свой вариант оправдательного богословия: заводской крестьянин Контауров перестал платить налоги, ссылаясь на то, что Бог дал землю без всяких пошлин. Такое положение якобы сохранялось до 1861 г., когда царь нарушил божий закон, следовательно, как нарушитель божественного порядка, он и есть Антихрист. Слуге дьявола «сыны Божии» служить не должны, что включает и неуплату налогов. Часть крестьян поддержала Контаурова, за разъяснениями обратившись к местным священникам. Последние приняли сторону властей, и тогда крестьяне решили, что Божией правды нет, и отвергли всю куль- 
товую практику православия, кроме чтения Библии и Евангелия [21, с. 238].

Еще один вариант неприятия мира официальной церкви и верховной власти - уверенность в скором конце мира. И если выше речь шла о бегстве от мира (мира официального православия), то здесь мир - это земной мир в целом, в противовес миру потустороннему. Многие старообрядческие толки носили ярко выраженный эсхатологический характер, что особенно было свойственно бегунам [19, с. 115]. В старообрядческой среде большой популярностью пользовался стих «Во миру жила девица», где есть такие строки:

Во миру девицу не возлюбили, Из миру красную прогнали.

Исполнительницей слова эти были прокомментированы следующим образом: «Это веру нашу максимовскую из миру прогнали, вот она в пустыню и ушла» [19, с. 115]. Здесь примечательна сама идея исключения, несправедливого наказания, мысль о сущностной несправедливости земного мира. Неслучайно исследователями были зафиксированы высказывания о том, что только в загробном мире человеку будет хорошо [18, с. 391].

В условиях снижения ценности существующей действительности становились актуальными представления о грядущем Царстве Божием. В.П. Чекин писал: «Бог и Царство Небесное неотступно стоят перед каждым уральским старовером» [37, с. 15]. Это Царство Христово, надо отметить, мыслилось старообрядцами по-разному. Зачастую оно имело почти точные географические ориентиры, локализуясь на Земле. Одной из наиболее известных версий стали представления о Беловодье мифической стране семидесяти островов старой веры, расположенной около Алтая [41, с. 24-31]. Тот же В. Москвин подразделял весь мир на небесный божий град Сион и земной град неправды Вавилон. Он в своих «Разглагольствованиях тюменского странника» обещал решающую битву носителей истинной веры с воинами Антихриста, под которыми подразумевались последователи патриарха Никона. Обещалось, что как высший судия сам Господь явится на белом коне, «сотворит брань» и дарует победу староверам. И возникнет царство правды на земле, столица которого - Новый Иерусалим - основана будет на берегу Каспийского моря [21, с. 189]. Известны и другие сюжеты, в которых старообрядцы уже не противопоставляли себя остальному населению страны: «Антихрист явится, когда русский народ овладеет Царьградом, победит турок, это будет при русском царе Константине» [23, с. 126]. Поэтому почти в каждом необычном явлении природы старообрядцы видели знак второго пришествия, грядущего суда Божиего и Царства Небесного. Особого внимания в этом качестве удостаивались небесные тела, подобно комете 1858 г. [5].

Неприятие сложившейся социальной системы в совокупности с эсхатологическими ожиданиями, усугубленные отсутствием точных дат грядущего апокалипсиca, актуализировали идею спасения души в миру. Многие верующие с этой целью отправлялись в скиты [37, с. 16], что находит отражение и в художественной литературе $[16,41]$. Организация скитов и «соборов», с одной стороны, рассматривались как путь к коллективному спасению через организацию праведной жизни [25, с. 43], одновременно являясь индикаторами геттоизированности сознания старообрядцев, предполагавших, что de facto только представители старой веры будут спасены на Страшном суде.

Очевидно, что в воззрениях на власть в старообрядческой среде прослеживаются два основных сюжета: власть представляет и защищает «неправильную» новую веру, веру «антихристову»; сама власть поэтому неправильная, нелегитимная, и значит, все виды ее воздействия несправедливы, что оправдывает выход из сферы экономического влияния государственной власти [32].

Таким образом, религиозная составляющая в социальной идентичности старообрядческого сообщества смыкается и частично замещается специфической стратегией экономического поведения, легитимированной эсхатологическими ожиданиями. Морфема «русский» в этих обстоятельст- 
вах начинает употребляться ситуативно, приобретая разную символическую нагрузку в различающихся политических и экономических обстоятельствах. Поэтому стоит говорить о конструктивистском характере самовосприятия и самопрезентации старообрядческого сообщества рубежа XIX$\mathrm{XX}$ вв., когда изначально единая модель религиозного и социального обособления была вытеснена мозаичной картиной миропредставлений, генерированной множественностью толков и согласий. Грядущий век усугубил плюрализм мнений, мифов и идей, постепенно выводя идейно-религиозное творчество и процессы самоидентификации на личностный уровень.

\section{Библиографический список}

1. Архиепископ Андроник. О церкви, России / сост. В.А. Королев. - г. Фрязино (Московская область), 1997.

2. Белавин А.М., Нечаев М.Г. Губернская Пермь. - Пермь, 1996.

3. Белогорский Свято-Николаевский православно-миссионерский мужской общежительный монастырь Пермской епархии. - Пермь, 1996.

4. Волгирева Г.П. Исихастские традиции в старообрядческих рукописях Прикамья // Старообрядческий мир Волго-Камья. - Пермь, 2001.

5. Воспоминания о комете 1858 г. // ПГВ. - 1860. - № 33.

6. ГАПК, Пермское губернское присутствие. Ф. 38. оп.1. д. 51.

7. ГАПК, Пермское губернское присутствие. Ф.38. оп.1, д. 355, л. 1-7 об.

8. Громыко М.М., Буганов А.В. О воззрениях русского народа. - М., 2000.

9. Димухаметова С.А. Мир вещей русских крестьян XIX-XX века: традиционная народная культура русского старообрядческого населения Верхокамья: из собр. Перм. краеведч. музея: каталог. Пермь: Пушка, 2010.

10. Ершова О.П. Старообрядчество и власть // Книжница Самарского староверия: интернет-библиотека. [Электронный pecypc] URL: http://samstar-biblio.ucoz.ru (дата обращения: 22.10.2018).

11. Из истории Урала. / Под ред. В.Я. Кривоногова, И.И.Бабикова, А.Г. Козлова. - Свердловск: Среднеуральское, 1971. - 390 с.

12. Колосов Н. Святыня русской души // ПГВ. - 1914. - № 154.

13. Королев В. Любовью побеждая страх // Гребневский листок. - 1995. - № 10.

14. Кузнецов А. Новый рассадник знаний // Уральский старообрядец. - Екатеринбург. - 1916. - № 8.

15. Лебедев И. Народный гимн // ПГВ. - 1877. - № 61.

16. Мамин-Сибиряк Д.Н. Приваловские миллионы. - Свердловск, 1980.

17. Машковцев B.B. Нормативное регулирование конфессиональной политики государства по отношению к старообрядцам в XIX - начале XX вв. // Русский мир: Сб. материалов Всерос. науч.практ. конф. «Русское старообрядчество в истории и культуре: прошлое и настоящее». - Пермь, 2010. - С. 151-163.

18. Немирович-Данченко В.И. Кама и Урал (очерки и впечатления). - СПб., 1904.

19. Никитина C.E. Устная традиция в народной культуре русского населения Верхокамья // Русские письменные и устные традиции и духовная культура (по материалам археографических экспедиций 1966 - 1980 гг.). - М., 1982.

20. Никитина C.E. Человек и социум в народных конфессиональных текстах (лексикографический аспект). - М.: Сов. писатель, 2009.

21. Никольский Н.М. История русской церкви. - М., 1930.

22. Новейшая история отечества. ХХ век: учеб. для студентов вузов: В 2 т. - Т. 1 / под ред. А.Ф. Киселева, Э.М. Щагина. - М., 1998.

23. Обозрение Пермского раскола: так называемого «старообрядства» / сост. А.П. [архимандрит Палладий (П.Е. Пьянков)]. - СПб, 1863.

24. Пермская рукопись ХІХ в. «О разделе». Публикация подготовлена E.M. Сморгуновой // Русские письменные и устные традиции и духовная культура (по материалам археографических экспедиций 1966 -1980 гг.). - М., 1982.

25. Поздеева И.В. Верещагинское территориальное книжное собрание и проблемы истории духовной культуры русского населения верховьев Камы // Русские письменные и устные традиции и духовная культура (по материалам археографических экспедиций 1966 -1980 гг.). - М., 1982.

26. Речь, произнесенная в заседании Православного Палестинского общества 2 декабря 1882 года вицепредседателем общества Т.И. Филипповым // ПЕВ. - 1883. - №17.

27. Россия. Полное географическое описание нашего Отечества. Урал и Приуралье. - СПб., 1914. - Т. 5.

28. Дневники экспедиции в Пермскую область Оханского района // РЭМ. Ф. 10, оп. 1, д. 42, л. 3.

29. Смилянская Е.Б., Сморгунова E.M. Памятники письменности Верхокамья: Приложения: Публикация рукописных текстов, Агеева, Кобяк, Круглова, Смилянская, 1994. 
30. Справочная книга Пермской епархии на 1912 г. - Пермь, 1911.

31. Таинственный мир // ПЕВ. - 1867. - № 17.

32. Теленков A.B. Национальное самосознание русских в конце XIX - начале XX вв. (на материалах Среднего Урала). - Пермь, 2012.

33. Титлянов В.В. Старообрядчество и «воровские деньги»// Старообрядческий мир Волго-Камья. Пермь, 2001.

34. Трушкова И.Ю. Старообрядчество в Омутнинском заводе Вятской губернии в ХІХ в.: исторические сюжеты и коллективные портреты. - С. 36-42.

35. Христианская культура Пермского Прикамья / Под ред. Н.3. Короткова, Л.В. Перескокова, Н.В. Казариновой, О.М. Власовой. - Пермь, 1998.

36. Чагин Г.Н. История в памяти русских крестьян Среднего Урала в середине XIX - начале XX века. Пермь, 1999.

37. Чекин В.П. Урал и Приуралье в произведениях Д.Н. Мамина-Сибиряка // Урал: Первый сборник «Зауральского края». - Екатеринбург, 1913.

38. Черных A.B. Старообрядчество южных районов Пермской области в контексте этнокультурной истории // Старообрядческий мир Волго-Камья. - Пермь, 2001.

39. Шилов A.B. Отчеты о состоянии раскола в Пермской епархии как источник по истории старообрядчества (по материалам РГИА) // Старообрядческий мир Волго-Камья: проблемы комплексного изучения: материалы науч. конф. - Пермь, 2001.

40. Щапов А.П. Русский раскол старообрядчества. - Казань: Изд-е книгопродавца Ивана Дубровина, 1859. $-548 \mathrm{c}$.

41. Pentikainen J. What is Old Belie? Who are the Starovery? // «Silent as Waters We Live». Old Believers in Russia and Abroad. - Helsinki, 1999. - P. 24, 31.

\title{
THE UNDERSTANDING OF POWER IN THE CONTEXT OF THE NATIONAL IDENTITY OF THE URAL OLD BELIEVERS AT THE END OF THE XIX - THE BEGINNING OF THE XX CENTURIES
}

\author{
A.V. Telenkov \\ Perm Federal Research Centre UB RAS
}

The article raises the question of the national identity of Russian old believers during the period of serious historical changes in all spheres of life - the turn of the XIX - early XX century (the materials of the Middle Urals are used). This period is characterized by rapid industrial growth, industrialization, which is called in science by the term «modernization». These changes also affected the spiritual life of the people, including the issues of self-identification. The phenomenon of national identity of Russians is complicated by the presence of a significant number of old believers. The nature of their ethnic identity is different from the bulk of the Russian people, primarily in relation to the government (both central and local). At the same time, the old believers are the keepers of Russian traditions, culture and literature, what unites them with the rest of the Russian people.

Keywords: national identity, old believers, Orthodoxy, official Church, Russian people, religious culture.

\section{Сведения об авторе}

Теленков Алексей Владимирович, кандидат исторических наук, научный сотрудник отдела по исследованию политических институтов и процессов, Пермский федеральный исследовательский центр УрО РАН (ПФИЦ УрО РАН), 614900, г. Пермь, ул. Ленина, 13А; e-mail: TelenkovAV@ucpermoil.ru 